\title{
IMPLEMENTASI CLOUD COMPUTING TECHNOLOGY UNTUK SMK PGRI 2 TANGERANG BERBASIS GAFE (GOOGLE APPS FOR EDUCATION)
}

\author{
Ari Asmawati' ${ }^{1}$, Ria Dwi I'zzaty ${ }^{2}$, Tasya Oktavianti ${ }^{3}$ \\ Dosen Manajeman Informatika STMIK Raharja ${ }^{1}$, Mahasiswa Sistem Informasi STMIK \\ Raharja ${ }^{2,3}$ \\ email:ariasmawati@raharja.info ${ }^{1}$,ria.dwi@raharja.info ${ }^{2}$,tasya.oktavianti@raharja.info
}

\begin{abstract}
ABSTRAK
Perkembangan teknologi yang begitu sangat cepat, mengharuskan setiap individu maupun pihak institusi mengikutinya. Seperti penggunaan clud computing yang penggunaannya saat ini sudah sangat luas. Di dalam dunia pendidikan, penggunaan cloud computing ini sangat bermanfaat untuk guru dan siswa dalam hal pembelajaran dikelas maupun di luar kelas. Apliakasi Gafe yang tersimpan dalam cloud menyediakan banyak pilihan aplikasi office , chat dan lain lain,. Sistem ini akan coba diterapkan di SMK PGRI 2 Tangerang yang saat ini masih menggunakan sistem manual. System ini memungkinkan antara guru dan siswa saling berkomunikasi dan saling berinteraksi antara satu dengan yang lainnya
\end{abstract}

Kata Kunci : Cloud computing, GAfE, Pendidikan, Software as a Service (SaaS).

\begin{abstract}
Technological developments that are so very fast, require that every individual or institution follow suit. Like the use of clud computing, the usage is currently very wide. In the world of education, the use of cloud computing is very useful for teachers and students in terms of learning in class and outside the classroom. Application of Gafe stored in the cloud provides many choices of office, chat and other applications. This system will try to be implemented in Tangerang PGRI 2 SMK, which is currently still using a manual system. This system allows teachers and students to communicate with each other and interact with each other
\end{abstract}

Keywords: Cloud computing, GAfE, Education, Software as a Service (SaaS). 


\section{PENDAHULUAN}

SMK (Sekolah Memengah Kejuruan) merupakan salah satu Lembaga Pendidikan di Indonesia yang sederajat dengan SMA (Sekoalah Menengah Atas), berbeda dengan SMA yang merupakan jenjang yang memang dipersiapkan untuk melanjutkan ke Universitas, tapi SMK lebih mempersiapkan Siswa-siswanya untuk dapat bekerja setelah lulus dari sekolah ini.

Cloud computing merupakan istilah yang baru di dunia komputasi, banyak yang salah persepsi dengan konsep cloud computing, yaitu selalu disamakan dengan internet. Cloud computing adalah suatu model komputasi yang memberikan kenyamanan keleluasaan dalam mengakses jaringan untuk memanfaatkan secara bersama suatu sumber daya komputasi yang terkonfigurasi (misalnya jaringan, server, penyimpanan Tradisional Harddisk, Network tempat penyimpanan atau storage serta aplikasi secara bersama-sama..

Di SMK PGRI 2 Tangerang memiliki jurusan Multimedia, Otomotif, Teknik Elektro dan Teknik Komputer dan Jaringan, dimana tugas-tugas dikumpulkan dalam bentuk foto, bentuk tulisan Word, file suara, dan video yang dimana ukurannya sangat besar. Saat ini di SMK PGRI 2 Tangerang dalm pengumpulan tugas masih bersfiat manual dengan mengumpulkan flashdisk atau dari handphone kepada guru yang bersangkutan. Cara ini banyak memiliki masalah, seperti waktu yang cukup lama dalam proses mentransfer file ke komputer guru tersebut sehingga waktu mengajar pun terpakai cukup banyak dan belum lagi penyebaran virus.

Tujuan penelitian ini adalah untuk memudahkan para siswa agar mudah dalam pengumpulan tugas sehingga tidak membuang waktu guru dalam memberikan pengajaran kepada siswa. Sehingga siswa pun dapat mengirimkan tugas dimana pun ia berada sampai tenggat waktu yang diberikan oleh guru.

\section{METODE PENELITIAN}

Definisi dari cloud computing masih bervariasi dan banyak orang masih tidak sepaham tentang apa itu cloud computing. Untuk aplikasi dan pengguna IT, cloud computing merupakan ItaaS (IT as a services). Menyediakan layanan komputasi, penyimpanan data, dan aplikasi dapat diakses melalui media Internet dari pusat data yang tersentralisasi. Untuk penyedia jasa layanan infrastruktur, cloud computing merupakan pusat data terdistribusi yang sifatnya masif dan terkoneksi dengan IP jaringan. Perbedaan pandangan tersebut secara jelas terefleksikan dalam layanan yang disediakan oleh penyedia layanan cloud seperti Google, Microsoft, dan Amazon [1].

Secara umum ada tiga jenis tipe layanan pada cloud computing, dimana pada ketiga arsitektur tersebut pengguna tidak mengatur secara langsung yaitu:

- Infrastructure as a Service (IaaS): IaaS menyediakan layanan sampai pada level Sistem Operasi..

- Platform as a Services (PaaS): PaaS menyediakan layanan pada level platform, jadi pengguna tidak lagi direpotkan dengan instalasi sistem operasi, web server, database server, dan aplikasi lainnya.

- Software as a Service (SaaS): SaaS menyediakan layanan langsung kepada pengguna dalam bentuk aplikasi yang sudah jadi. Bentuk layanan aplikasi yang ditawarkan seperti layanan aplikasi office, email, layanan penyimpanan data, dll. Contoh layanan SaaS adalah: Office 365, Gmail, Google Docs, DropBox, dan Salesforce. 


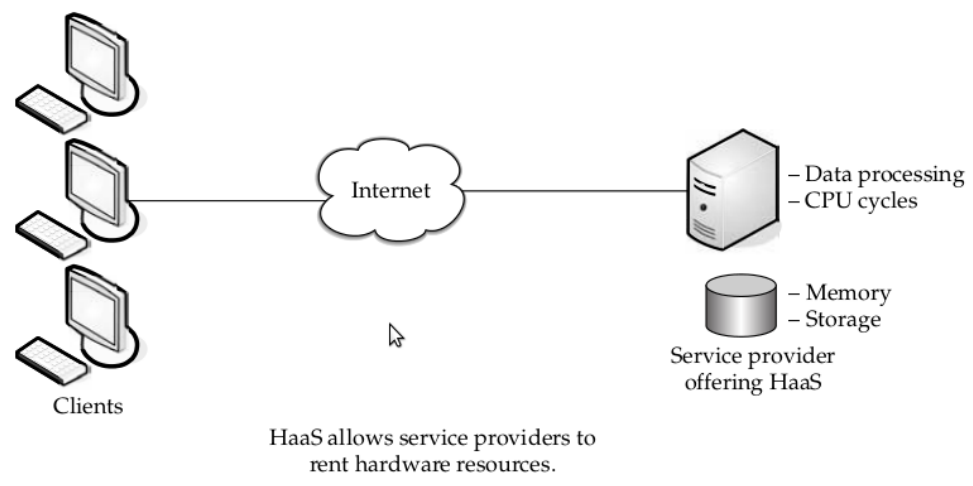

Gambar 1. IaaS (Infrastructur as a Service).

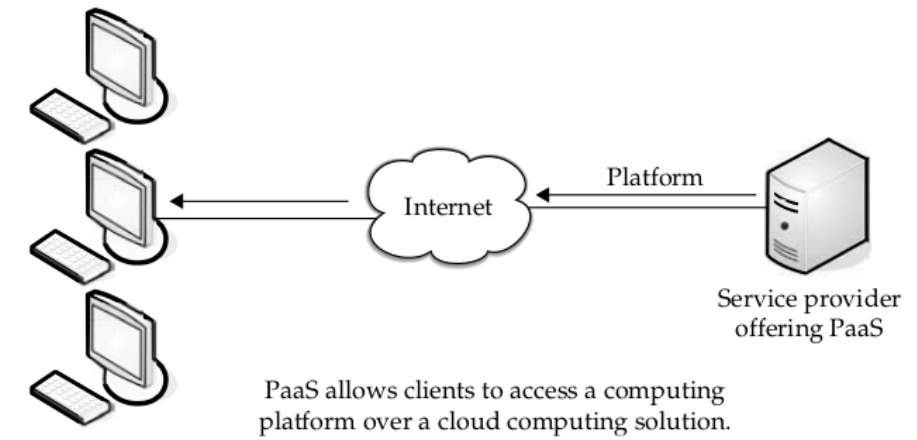

Gambar 2. PaaS (Platform as a Service).

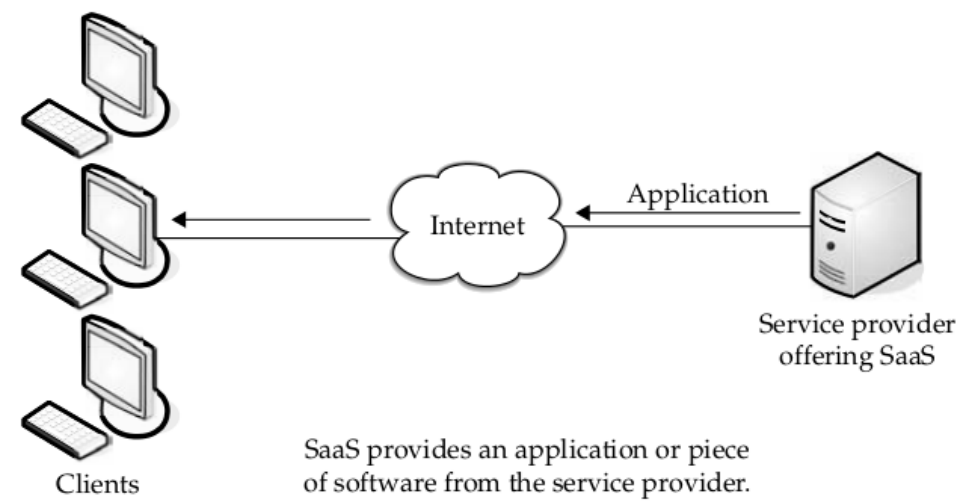

Gambar 3. Saas (Software as a Service).

Cloud Computing menyediakan banyak layanan online yang dapat membantu pihak Sekolah untuk mendukung skenario proses belajar dan mengajar secara lebih luas. Aplikasi yang disediakan umumnya adalah aplikasi berbasis web yang mudah untuk diakses dari mana saja, kapan saja melalui media Internet [14].

\section{GAfE (Google Apps for Education)}

Google Apps for Education adalah layanan google untuk dunia pendidikan , semua pendidikan dan Universitas . Google memberikan solusi dan pemecahan untuk komunikasi yang terintegrasi dengan email, kalender dan chat dan solusi berkolaborasi yang digunakan berbarengan 
Google Apps For Education terdiri dari:

- Gmail: Account email untuk masing-masing siswa dengan fasilitas, fungsi dan kapasitas sama seperti account gmail reguler, 10 GB sehingga membantu siswa dalam mencari informasi dengan cepat dan instant.

- Google Calendar: Siswa dapat mengorganisir rencana kegiatan dan event yang kemudian dapat di bagikan pada yang lainnya.

- Google Talk: Siswa dapat memanggil dan mengirim pesan pada yang lainnya setiap saat, dari manapun di muka bumi ini.

- Google Docs: Siswa dapat berbagi file dokumen, spreadsheet dan presentasi. Kolaborasi dalam waktu yang nyata (real time) dengan kelompok dalam satu sekolah dan hasilnya di publikasikan pada dunia.

- Google Sites: Kerja sama untuk menjaga hubungan antar dokumen, isi web dan informasi lain pada satu tempat

- Google Video for Educations: Video hosting dan sharing untuk internal sekolah untuk mengefektifkan kerja sama.

Aplikasi umum seperti Google Apps for Education memberikan aplikasi online untuk mendukung kemampuan perkantoran seperti penggunaan word processing, spread sheet, dan presentation yang dapat digunakan di kelas. Pengajar dapat menggunakan teknologi tersebut dalam berbagai cara, sebagai contoh pengajar menggunakan Google Spreadsheet untuk menampilkan nilai yang di bagikan secara online kepada mahasiswa [2]. Dosen atau guru dan mahasiswa juga dapat menggunakan akun Google atau Microsoft untuk email yang dikombinasikan dengan nama domain dari institusi tersebut [7], menggunakan media video streaming untuk menampilkan video pembelajaran [3], atau memanfaatkan media penyimpanan berbasis cloud seperti OneDrive atau Dropbox dalam penyimpanannya[6].

Menurut Google, inc, Google Apps for Education atau GAfE berisi banyak fitur keamanan penting yang secara khusus dirancang agar data Anda tetap aman, terlindung, dan berada dalam kontrol Anda secara real time. Data Anda adalah milik Anda dan alat Apps memungkinkan Anda untuk mengontrolnya, termasuk kepada siapa dan bagaimana Anda membagikannya.

\section{PERMASALAHAN}

Perkembangan teknologi yang sangat cepat membuat semuanya harus cepat mengikuti perkembanannya. Contohnya, seperti dalam dunia pendidikan yang harus bisa mengikuti arus perkembangan untuk memudahkan setiap aktifitas dalam kegiatan mengajar. Banyak saat ini sekolah yang dalam kegiatannya masih bersifat manual. Contohnya, dalam pengumpulan tugas yang dapat membuang waktu mengajar hanya untuk pengumpulan tugas. Yang dimana tugas itu dalam ukuran yang cukup besar. Sehingga waktu belajar pun berkurang. Lalu banyak juga siswa yang lupa pada waktu pengumpulan tugasnya dikarenakan adanya tugas dari guru mata pelajaran lain.

Rumusan masalah dalam penelitian ini adalah bagaimana caranya agar memudahkan siswa dalam pengumpulan tugas tanpa mengurangi waktu efektif belajar dan memudahkan guru tanpa harus membawa laptop kedalam kelas untuk pengumpulan tugas. Dan membuat siswa juga dapat mengetahui kapan tugas itu harus dikumpulkan.

Karena beberapa masalah yang sudah disebutkan diatas, maka peneliti berinisiatif untuk membuat alternatif lain yaitu dengan layanan email.Yaitu dengan membuat sistem cloud computing berbasis GAfE. Sistem gratis yang ditawarkan Google dengan model SaaSsehingga tidak sangat memudahkans sekolah karena tidak harus menyediakan perangkat-perangkat keras seperti komputer server dan sebagainya. Karena sudah otomatis tersimpan pada server cloud 
yang disediakan Google. Sehingga siswa bisa mengirimkan tugasnya dimana saja dan kapan saja. Siswa hanya perlu membuat akun gmail sendiri yang nantinya guru hanyatinggal menginutnya ke Google Apps for Education.

\section{Literature Review}

Literature review ini digunakan untuk sebagai ajuan penulis tidak menggunakan hasil karya orang lain sebagai plagiat, serta menjadi ajuan untuk pemanfaatan penelitian selanjutnya, beberapa penelitian yang serupa atau ajuan penulis diantaranya :

1. Jurnal yang dibuat oleh Enang rusnandi dan Deffy susanti, Jurnal Computech \& Bisnis, Vol. 6, No.1 Juni 2012 Cloud Computing Technology merupakan salah satu teknologi yang dapat membantu mempermudah organisasi melakukan aktivitas yang berhubungan dengan komunikasi data dan informasi. Bagi perguruan tinggi, kebutuhan penggunaan cloud computing technology ini merupakan sebuah kebutuhan yang mendesak yang dapat digunakan sebagai support system yang dapat menunjang proses bisnis yang ada, selain berguna untuk kelancaran proses komunikasi data dan informasi, baik secara internal maupun eksternal.[5]

2. Jurnal Ticom yang dibuat oleh Fredy Susanto dan Pajar sahputra, Universitas Budi Luhur, Vol,1 No.3, 2013yang isi nya adalah Teknik pencarian pada google sudah umum dipergunakan oleh semua kalangan, mesin pencari ini memberikan informasi semua hal yang dibutuhkan, termasuk informasi gambar dan peta. Pengkodean dengan Steganografi adalah penyisipan informasi ke dalam sebuah media seperti media gambar , suara maupun video. Penyampaian pesan di dalam google dapat memberikan informasi terhadap orang yang dituju pada media publik yang dienkripsi. Penyisipan informasi ke dalam gambar suatu lokasi pada google map marker, merupakan sebuah teknik penyampaian informasi kepada orang yang dituju ke dalam dimensi yang berbeda. Semua orang tidak akan mengira bahwa dalam gambar tersebut terdapat informasi rahasia yang dapat mencirikan tempat yang dituju tersebut.[4]

3. Jurnal CERITA Vol.4, No.1 Syafnidawaty. Teknologi sistem pelacakan (tracking) realtime telah dimungkinkan dengan menggunakan mikrokontroler seperti arduino uno dan module GPS. Tulisan ini mengajukan mekanisme pelacakan kendaraan pada sebuah rental bus dengan GPS Tracker untuk membuat suatu sistem informasi monitoring kendaraan secara realtime. Beberapa komponen seperti Arduino Uno, SIM908 Modul, antena, dan baterai dirangkai sedemikian rupa untuk kemudian memproses data posisi kendaraan dan mengirimnya dengan menggunakan request HTTP ke web server melalui paket data/internet. Sebuah halaman web dirancang sebagai output berupa peta digital yang dapat diakses melalui web browser.Rekayasa dari teknologi tersebut dapat menghasilkan sistem pemantauan obyek bergerak yang memang sangat perlu diketahui keberadaan dan pergerakannya untuk membantu mencapai kinerja perusahaan yang optimal.[13]

\section{HASIL DAN PEMBAHASAN}

Untuk mengatasi berbagai masalah siswa dan guru dalam kegiatan belajar dan mengajar, maka diperlukan sistem yang mempermudah para siswa untuk mengingatkan tentang tugas mereka lalu memudahkan mereka dalam pengumpulan tugas dan memudahkan guru dalam mengoreksi setiap tugas tanpa harus mengorbankan waktu mengajar. Pada pemecahan masalah menggunakan metode analisa terhadap sistem yang berjalan di sekolah tersebut, maka akan didapatkan suatu hasil sistem yang memudahkan guru dan siswa dalam kegiatan belajar dan mengajar. 


\section{LOGIKA DAN FLOWCHART}

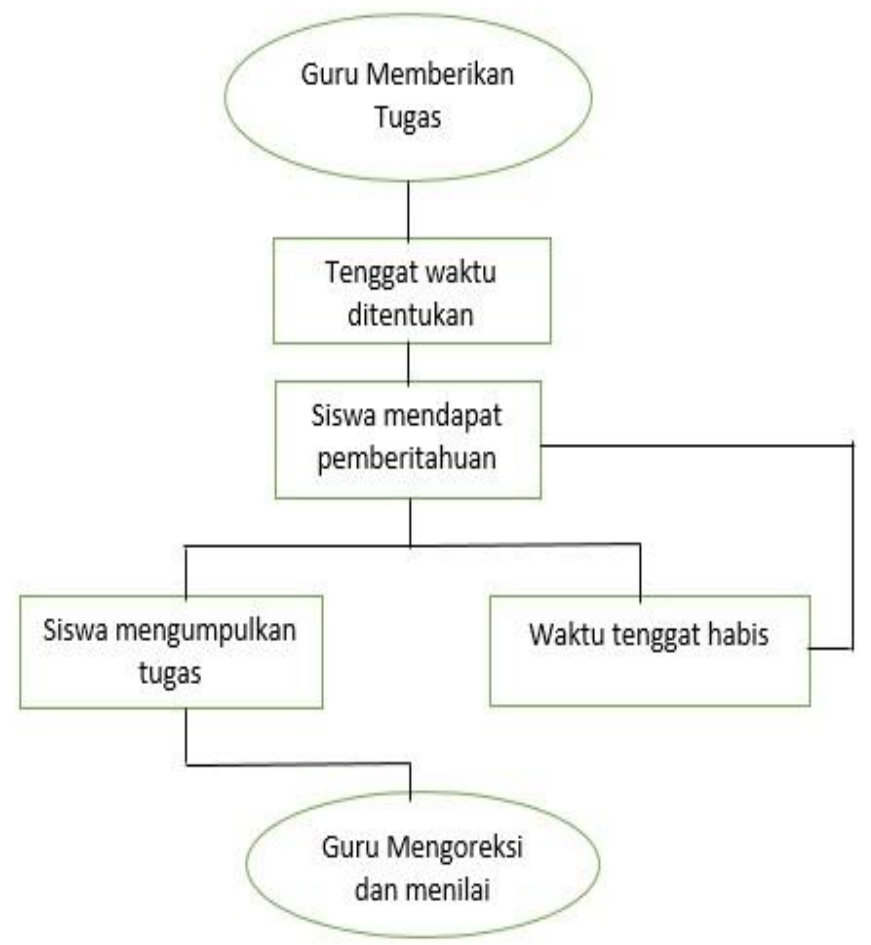

Gambar 4. Alur Sistem

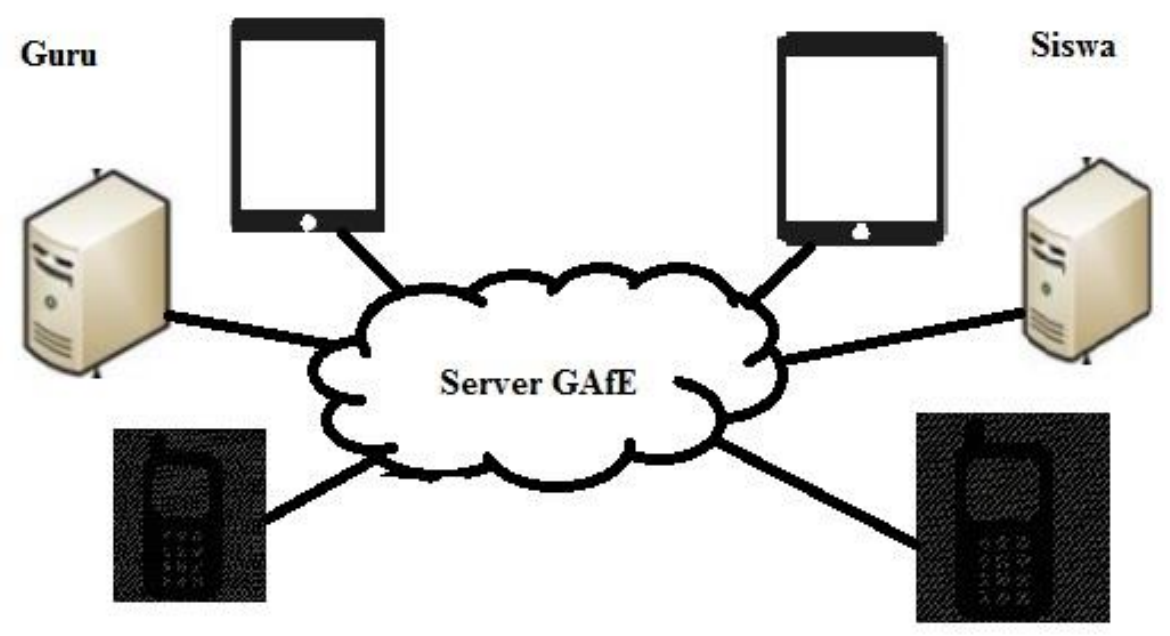

Gambar 5. Cara Kerja Sistem

\section{IMPLEMENTASI}

Pembuatan akun sekolah SMK PGRI 2 Tangerang untuk memudahkan admin untuk mengelola sistem tersebut. Contohnya membuat organisasi, suborganisasi sebagai wadah untuk akun siswa dan guru. Hal pertama yang harus dibuat yaitu organisasi. Ini dibuat agar memudahkan dalam pengklasifikasian suborganisasi yang nantinya di dalam masing-masing suborganisasi terdapat akun-akun siswa dan guru. 


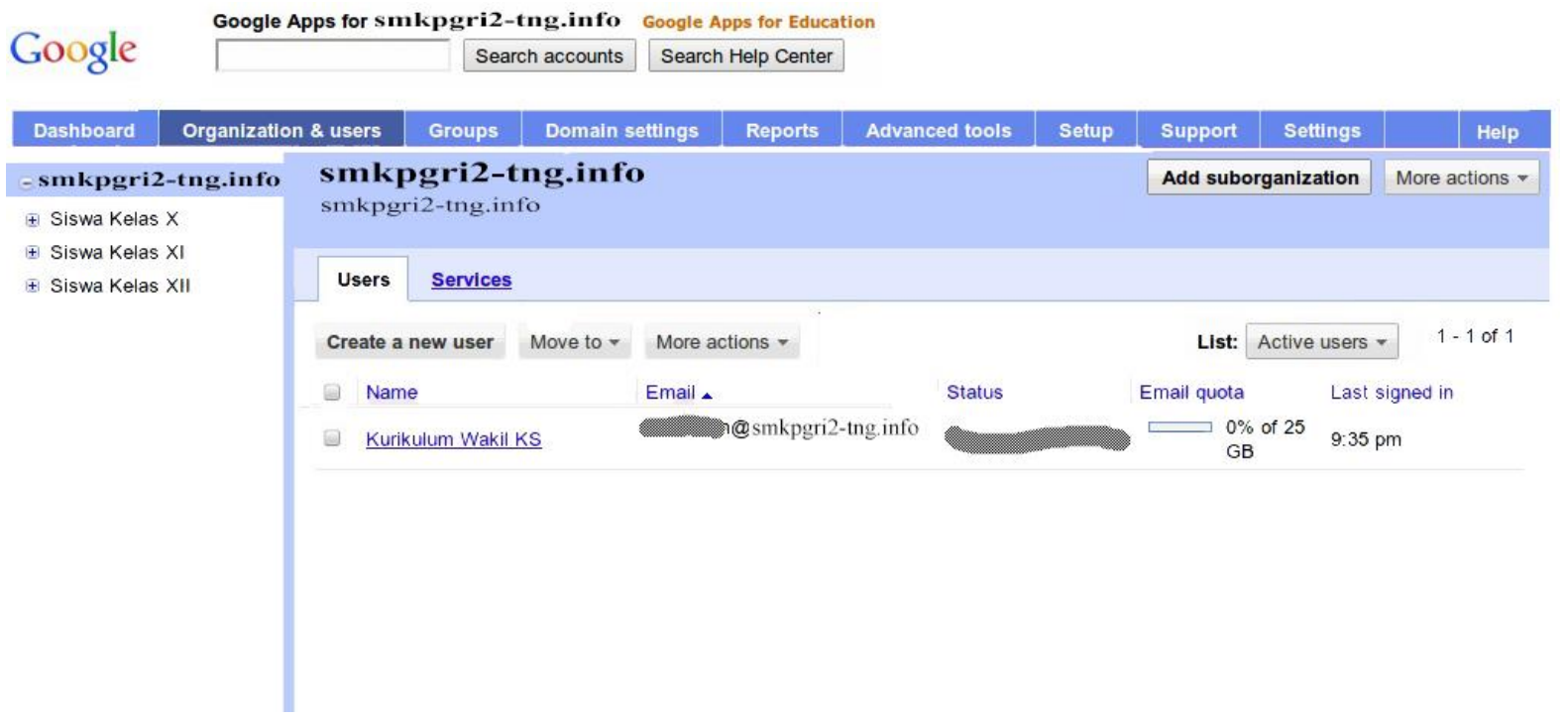

Gambar 6. Organisasi Sekolah

Lalu membuat suborganisasi, yaitu isinya seperti daftar guru, daftar kelas, di dalam daftar kelas adapun daftar mata pelajaran yang nantinya itu memudahkan guru untuk memberikan tugas, menilai tugas, sehingga guru juga bisa tahu siapa yang mengerjakan atau tidak.

\section{Dashboard Organization \\ $\Theta$ smkpgri2-tng info \\ 曰 Siswa Kelas X \\ $\mathrm{X}$ TK.J 1 \\ $\mathrm{XL} 1$ \\ $X \mathrm{~L} 2$ \\ $\mathrm{X}$ MM 1 \\ $\mathrm{XMM} 2$ \\ $\boxplus$ Siswa Kelas XI \\ Đ Siswa Kelas XII}

Gambar 7. Suborganisasi 


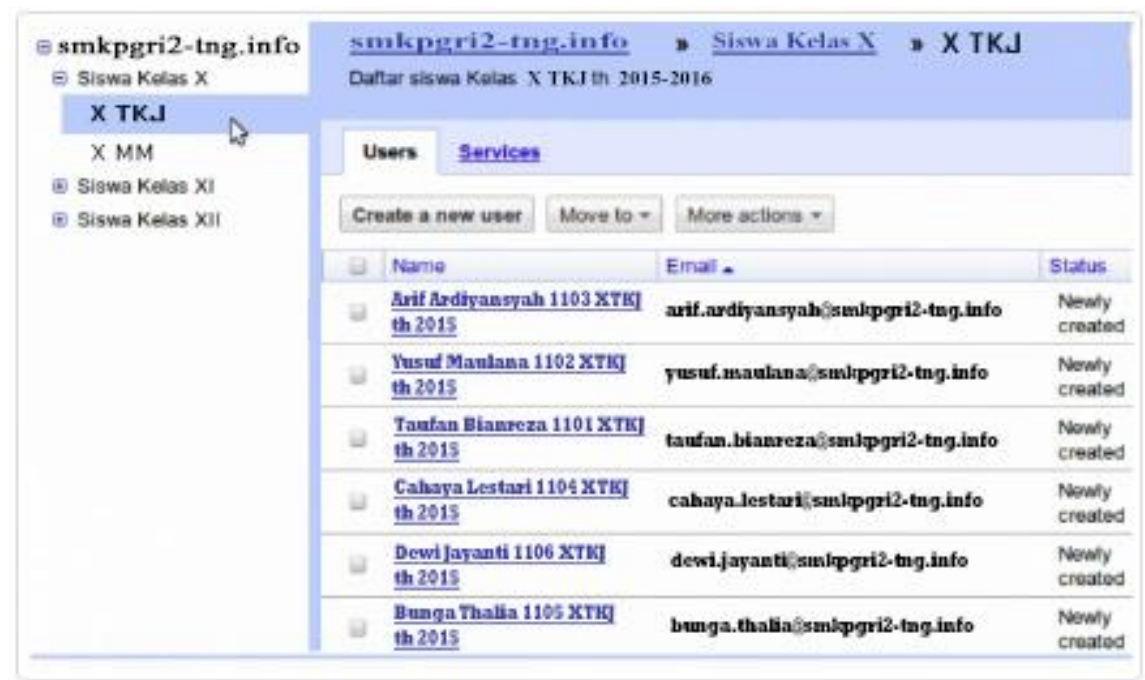

Gambar 9. Pengujian sistem.

\section{KELEBIHAN}

Dengan menggunakan sistem ini sangat memudahkan guru, siswa dan sekolah. Sistem ini memudahkan siswa dalam mengumpulkan tugas, guru pun mudah dalam menilai para siswa. Terlebih lagi layanan cloud computing ini gratis, selain itu tidak memerlukan backup komputer lokal karena semua sudah ada dalam server cloud. Setiap siswa pun dapat mengirimkan tugas dimana pun mereka berada, begitu juga para guru dapat mengaksesnya dimana pun mereka berada. Didukung dengan penyimpanan yang cukup besar.

\section{KEKURANGAN}

Meskipun sistem ini memudahkan guru dan siswa, namun ada beberapa hal yang menjadi kekurangan dalam sistem ini, yaitu kerahasiaan data serta ketidakpastian untuk memulihkan data. Selain itu harus membutuhkan koneksi internet dan sulit bagi yang belum terbiasa mengerjakan tugasnya dengan sistem ini apalagi yang belum terbiasa mengetik di PC atau Laptop.

\section{KESIMPULAN}

Cloud Computing adalah komputasi baru dan merupakan teknologi masa depan yang memudahkan setiap orang dengan berbagai layanan yang apik. Saat ini sudah mulai banyak berbagai institusi yang menggunakan sistem cloud computing sebagai sarana dalam segala aktifitas di institusi tersebut. Begitu banyak manfaat yang disediakan sehingga penulis mencoba menerapkan sistem ini di SMK PGRI 2 Tangerang untuk kegiatan belajar mengajarnya. Dalam penggunaannya para guru dan siswa dapat mengakses setiap pembelajaran dimana saja seperti pengumpulan tugas, dan penilaian guru. Namun meski begitu memudahkan tetap saja ada beberapa kekurangan yaitu harus selalu membutuhkan koneksi internet untuk mengaksesnya. 


\section{DAFTAR PUSTAKA}

[1] Ahmadi, A. (2009). ISU-ISU KEAMANAN CLOUD COMPUTING. Jurnal C omputech \& Bisnis, 3(2), 76-83.

[2] Blood, E. (2011). "Point systems made simple with Google docs". Intervention in School and Clinic, 46(5), 305-309.

[3] Dmitriev, S., Kononov, A., Shiriaev, M., \& Malozemov, S. (2012). "Cloud computing for education in state technical University of Nizhny Novgorod". Proceedings of the 9th IFAC.

[4] Fredy susanto dan Pajar Sahputra, Jurnal TICOM Universitas Budi Luhur Vol.1,no.3, 2013. Hidden Messages pada Google Map Marker Images Menggunakan Teknik Steganografi

[5] Rusnandi, Enang. \& Deffy, Susanti. (2012) PERENCANAAN STRATEGIS CLOUD COMPUTING TECHNOLOGY BERBASIS Gafe (GOOGLE APPS For EDUCATION ) BAGI PERGURUAN TINGGI SWASTA DI WILAYAH III CIREBON PROPINSI JAWA BARAT. Jurnal Computech \& Bisnis, Vol. 6, No. 1, Juni 2012, 1-16

[6] Lennon, R. G. (2012). "Bring your own device (BYOD) with cloud 4 education". Proceedings of the 2012 3rd Annual Conference on Systems, Programming, Languages and Applications:

[7] Sclater, N. (2010). "eLearning in the Cloud. International Journal of Virtual and Personal Learning Environments", 1(1), 10-19.

[8] Sofana, I. (2012) Cloud Computing, Teori dan Praktek (OpenNebula, Vmware dan Amazon AWS). Bandung : Informatika

[9] Sosinsky, B. (2011) Cloud Computing Bible.Indiana: Wiley Publishing.

[10] Targowski, Andrew. (2003) Electronic Enterprise: Strategy and Architecture.IRM Press,Hershey.

[11] Shariff, Johan. (2016) Membangun Private Cloud Computing dan Analisa Terhadap Serangan DoS, Study Kasus SMKN 6 Jakarta.

[12] Syafnidawaty Jurnal CERITA Vol.4, No1 Prototyoe pemantau BUS Menggunakan GPS tracking Geolocation Berbasis Arduino.

[13] Kurniawan, Erick. (2015) IMPLEMANTASI TEKNOLOGI CLOUD COMPUTING DI UNIVERSITAS Studi Kasus: Fakultas Teknologi Informasi UKDW

[14] Zulficar, Muhammad. (2013) IMPLEMENTASI CLOUD COMPUTING DENGAN SOA(SERVICE ORIENTED ARCHITECTURE) PADA SISTEM INFORMASI AKADEMIK.

[15] Wu, C. F., \& Huang, L. P. (2011). "Developing the environment of information technology 